\title{
Kronik boyun ağrılı hastada ayırıcı tanı
}

\section{Differential diagnosis in patients with chronic neck pain}

\author{
Elif Akalın
}

Dokuz Eylül Üniversitesi Tıp Fakültesi Fiziksel Tıp ve Rehabilitasyon Anabilim Dalı, İzmir

\begin{abstract}
Boyun ağrısı, toplumda yaygın olarak görülen ve farklı nedenlerle ortaya çıkabilen bir yakınmadır. Çoğunluğu omurga ve çevresi yumuşak dokulardan kaynaklanmakla birlikte, omurga dışı dokulardan yansıyan ağrılar da olabilir. Hastanın öyküsü ve fizik bakı özellikleri, ayırıcı tanı açısından çok değerlidir. Boyun ağrılı hastanın ayırıcı tanısında ilk adım, altta yatan olası ciddi bir patolojinin varlığının ekarte edilmesidir. Bundan sonraki adım, mekanik boyun ağrısının radikülopati ya da miyelopatiden ayrımının yapılmasıdır.
\end{abstract}

Anahtar sözcükler: boyun ağrısı; kronik; ayırıcı tanı
Neck pain is a common complaint in society and occur due to different causes. The majority may originate from the spine and soft tissues around to spine as well as from the non-spine tissues. The characteristics of the patient's history and physical examination are valuable in terms of differential diagnosis. The first step in the differential diagnosis of a patient with neck pain is to exclude the possible underlying severe pathology. Second step is to differentiate the mechanical neck pain from radiculopathy or myelopathy.

Key words: neck pain; chronic; differential diagnosis

- Radiküler boyun ağrısı

- Servikal disk hernisi

- Servikal spondilotik miyelopati

2. Servikal omurga majör klinik hastalıkları

- Romatizmal hastalıklar

- Polimiyaljia romatika

- Romatoid artrit

- Ankilozan spondilit, psöriatik artrit, Reiter sendromu

- Juvenil romatoid artrit

- Diffüz idiyopatik skeletal hiperostoz (DISH)

- Tümörler: malign-benign

- Enfeksiyonlar: diskit, vertebral osteomiyelit, herpes zoster, abseler

3. Yansıyan ağrılar

- Kalp-aort

- Hiatus hernisi

- Akciğer apeksi

- Safra kesesi - özofagus - pankreas

- İletişim adresi: Prof. Dr. Elif Akalın, Dokuz Eylül Üniversitesi Tıp Fakültesi Fiziksel Tıp ve Rehabilitasyon Anabilim Dalı, İzmir Tel: 0232 - 4644614 e-posta: elif.akalin@deu.edu.tr

- Geliş̧ tarihi: 20 Șubat 2017 Kabul tarihi: 20 Șubat 2017 
Boyun ağrısıyla gelen bir hastada tanı ve ayırıcı tanıda birinci adım, hastanın yakınmalarının kaynağının kas iskelet sistemi mi yoksa omurga dışı bir hastalık veya ciddi spinal patoloji mi olduğunun ayırt edilmesidir. Hastanın ağrısının kas iskelet sistemi kaynaklı olduğuna karar verilirse, bu kez ağrının sinir kökü basısı yapan bir durum ya da non-spesifik bir boyun ağrısı olup olmadığını araştırmak için ikinci basamaga geçilir. ${ }^{[3]}$ Kronik boyun ağrısıyla gelen bir hastada, öncelikle ağrıya yol açabilecek altta yatan ciddi hastalıkların olasılığı bilinmeli ve bunlara yönelik işaretler doğru değerlendirilmelidir. ${ }^{[4]} \mathrm{Bu}$ işaretler; hastada yakın zamanda travma öyküsü, açıklanamayan kilo kaybı, ateş, kanser öyküsü, immünsupresyon, intravenöz ilaç bağımlılığı, kronik steroid kullanımı ya da yürüme güçlüğü, mesane-barsak disfonksiyonu, nörolojik semptom veya bulgunun olmasıdır. Bu bulgular, boyun ağrısının kırmızı bayrakları olarak aşağıda özetlenmiştir ${ }^{[1]}$ :

1. Travma: minör ya da travmanın olmadı̆̆ı osteoporoz veya kortikosteroid kullanımına bağlı kemik kaybı olan hasta.

2. Malignite: kanser öyküsü, açıklanamayan kilo kaybı, konstitüsyonel semptomlar, bir aylık tedaviye yanıtsız hasta.

3. Spinal kord kompresyonu: servikal miyelopatili hasta (servikal miyelopatili hastaların yaklaşık yarısında boyun ve/veya kol ağrısı vardır). Kol ve bacaklarda semptom, mesane ve barsak problemleri.

4. Sistemik hastalıklar: inflamatuvar artriti olan hasta

5. Enfeksiyon: intravenöz ilaç bağımlılığı, üriner enfeksiyon, deride enfeksiyon.

6. Ağrı: inatçı ağrı, vertebra cismi üzerinde hassasiyet.

7. Önceki medikal öykü: önceden geçirilmiş boyun cerrahisi öyküsü olan hasta.

Boyun ağrısı olan bir hastada ayırıcı tanıda, spesifik hastalıkları düşündüren bulgulara da dikkat edilmesi gerekir. Boyun ağrısı ile beraber baş ağrısı, görmede bozulma, omuz ve kalça çevresi ağrı, tutukluk varsa ve laboratuvar bulguları destekliyorsa, polimiyaljia romatika akla gelmelidir. ${ }^{[1]}$ Ankilozan spondilit ve romatoid artrit gibi inflamatuvar romatizmal hastalıkların seyri sırasında da boyun ağrısı görülebilir.

Boyun ağrısı ile beraber ateş, üşüme, titreme, beklenmedik kilo kaybı olması, tümör ya da enfeksiyonu akla getirmelidir. Vertebral osteomiyelit, etkilenen vertebra düzeyinden servikal paraspinal kaslara yayılan keskin ağrı ve spazmla seyreder. Etkilenen vertebra üzerinde kompresyonda şiddetli ağrı gözlenir. Diskitte, enfekte disk çevresinden omuza yayılan çok şiddetli ve keskin ağrı vardır; lokalize hassasiyet, şiddetli hareket kısıtlılığı eşlik eder. Benign tümörler ya da multipl miyelom, kondrosarkom, kemik metastazları, intraspinal neoplaziler, lenfoma, kordoma gibi malign oluşumlar da boyun ağrısına yol açabilecek klinik durumlardır. ${ }^{[4,5]}$ Boyun ağrısı ile beraber kollarda güçsüzlük yürüme güçlüğü mesane ve barsak disfonksiyonu varsa veya Babinski ya da Hoffman bulgusu pozitifse, servikal miyelopati akla gelmelidir. ${ }^{[5]}$

\section{YANSIYAN AĞRILAR}

Boyun ağrıları, omurga dışı organ ve dokulardan yansıyan ağrı şeklinde de ortaya çıkabilir; servikal omurga dışından kaynaklanır, ancak boyunda ve çevresinde algılanır. Servikal kök innervasyonu, aynı embriyolojik kökenli olan somatik ve visseral yapıların rahatsızlıkları, boyunda hissedilen ağrıya yol açabilir. Bu alanlar, refleks olarak sinir kökünün segmental dağılımı boyunca yayılan ağrıya yol açar. Fizik bakıda palpasyonda hassas değildir; kas spazmı yoktur; yanma ve kramp duyusu şeklinde tanımlanır. Bu ağrılar ve klinik özellikleri şunlardır ${ }^{[5]}$ :

- Vasküler yansıyan ağrılar:

$\sqrt{ }$ Miyokard infarktüsü:

- Ağrının karakteri: ezilme

- Lokalizasyonu: anterior boyun-kol (C8)

- Öyküde: angina, hipertansiyon vb. vardır.

- Fizik bakı: kas iskelet bulgusu yok. Kardiyak testler $(+)$.

$\sqrt{ }$ Karotis disseksiyonu:

- Ağrının karakteri: keskin, ısrarlı

- Lokalizasyonu: unilateral, boyundan başa yayılır.

- Öyküde: sigara, fibromusküler displazi

- Fizik bakı: fokal nörolojik defisit, karotis üfürümü olabilir.

$\sqrt{ }$ Torasik aort disseksiyonu:

- Ağrının karakteri: yırtıcı

- Lokalizasyonu: göğüsten lateral posterior boyuna yayilır.

- Öyküde: yaşlı, aterosklerotik kalp hastalığı vardır.

- Fizik bakı: hipotansiyon 
- Safra kesesi - akut kolesistit kaynaklı ağrılar

- Ağrının karakteri: şiddetli, kolik tarzında

- Lokalizasyonu: sağ paraspinöz, sağ skapula çevresi olabilir.

- Öyküde: bulantı, kusma, 40 yaş üzeri kadın

- Fizik bakı: ateş, abdominal ağrı

- Özofagus kaynaklı ağrılar:

- Ağrının karakteri: künt, bazen yanıcı ağrı

- Lokalizasyonu: anterior, göğüsten boyuna yayılabilir.

- Öyküde: disfaji

Hastanın yakınmalarının kas iskelet sistemine bağlı bir boyun ağrısı olduğu düşünülüyorsa, öncelikle bunun sinir kökü basısının eşlik ettiği bir ağrı mı yoksa non-spesifik bir ağrı mı olduğu ayırt edilmelidir. ${ }^{[6]}$ Negatif nörolojik bakı, kök kompresyonu olasılığının çok az olduğunu işaret eder, ancak pozitif bulgu kök kompresyonuna çok spesifik değildir. Spurling manevrası, yüksek prediktif değere sahiptir. ${ }^{1}$ Boyun ağrısı ile ilgilenen bir grup araştırıcı, boyun ağrılarının tanı ve tedavi süreçlerini kanıta dayalı veriler eşliğinde yönetmek üzere 2008 yılında toplanarak bir grup öneri getirmişlerdir. Bu önerilerin başında, boyun ağrılarının klinik sınıflaması vardır. Bu sınıflamaya göre:

Grade I: Majör patolojik bulgunun olmadığı, günlük aktiviteleri minimum etkileyen ve en sık görülen boyun ağrısıdır. Ciddi bir patoloji yoktur. Boyun ağrısı, sertlik ve palpasyonda duyarlılıkla birlikte olabilir. Anlamlı nörolojik yakınma yoktur. Vertebral kırık, dislokasyon, spinal kord ya da sinir etkilenmesi, enfeksiyon, neoplazi veya inflamatuvar hastalıkları da içeren sistemik hastalıklara ait semptom ve bulgu yoktur.

Grade II: Majör patolojik bulgunun olmadığı, ancak günlük yaşamı etkileyen boyun ağrısı tipidir. Anlamlı sinir kökü basısı ya da ciddi yapısal patoloji yoktur.

Grade III: Nörolojik semptom ve bulgunun eşlik ettiği boyun ağrısıdır. Sık değildir, ancak spesifik tanı ve tedavi gerektirir. DTR'de (derin tendon refleksleri) azalma, kas güçsüzlüğü ve/veya duyusal etkilenme ya da spinal sinir ya da spinal kordda fonksiyon bozukluğu olabilir. Nörolojik bulgu olmadan sadece üst ekstremitede ağrı ve uyuşma Grade III için yeterli değildir.

Grade IV: Majör patolojik bulgu (kırık, instabilite, miyelopati, neoplazi, spinal enfeksiyon) ile birlikte olan boyun ağrısıdır. Nadir, ancak acil tanı ve tedavi gerektirir. Kırık, miyelopati, enfeksiyon, neoplazi, inflamatuvar artropatiler gibi sistemik hastalıklara yapısal patolojinin eşlik ettiği boyun ağrısıdır. Klinisyenler için, bu grubu diğerlerinden ayırt etmek çok önemlidir. Kırmızı bayrak işaretlerine karşı dikkatli olunmalıdır. ${ }^{[1]}$

\section{AKSIYEL BOYUN AĞRISI NEDENLERi}

Aksiyel boyun ağrısının en sık nedeni, servikal omurgadaki dejeneratif değişikliklerdir. Ancak bunun dışında, servikal bölgedeki kasların zorlanması, kamçı yaralanmaları, servikal faset sendromu, servikal miyofasyal ağrı, servikal diskojenik ağrı ve romatoid artrit, ankilozan spondilit, polimiyaljia romatika gibi bazı inflamatuvar romatizmal hastalıkların seyri ya da kemik metastazları ile birlikte aksiyel boyun ağrısı olabilir.

\section{Servikal Strain}

Nonspesifik bir tanıdır. Akut boyun ya da trapez kas zorlanması ile ortaya çıkan ve nörolojik disfonksiyon dışlandığında konulan tanıdır. Boyun ve sırtta ağrı, sertlik ve gerginlik vardır. Servikal paraspinal kas ve bağlarda zorlanma/spazm vardır. Kötü postür en önemli nedenidir. Semptom süresi genellikle 6-8 haftanın altındadır.

\section{Servikal Diskojenik Ağrı}

Servikal dejeneratif disk hastalığı, klinik bir tablodan çok, çoğu zaman radyolojik bir tanıdır. Asemptomatik bireylerde de görülme sıklığı yüksektir. Yapılan bir manyetik rezonans (MR) görüntüleme çalışmasında, yaş ortalaması 39 olan asemptomatik 223 kişinin 12 yıllık izleminde, $\% 81$ oranında servikal disk dejenerasyonu geliştiği gösterilmiştir. ${ }^{[7]}$ Bu nedenle, semptomatik hastaları tanımlamak için, servikal dejeneratif disk hastalığı yerine "servikal internal disk yırtılma (disruption ) sendromu" ya da "servikal diskojenik ağrı" ifadesi kullanılmaktadır. ${ }^{[8,9]}$ Servikal diskojenik ağrı, boyun ağrısının en sık nedenidir. Servikal disk herniyasyonunun aksine, diskojenik ağrı diskin mimari yapısında bozulmadır ve klinikte mekanik boyun ağrısı şeklinde kendini gösterir. Diskin iç yapısındaki bu bozulma, normal disk fonksiyonu olan intervertebral basıncın disk, vertebral son plak ve faset eklem arasında etkin olarak dağıtılmasında yetersizlik yaratır.

Servikal diskojenik ağrıda, aksiyel boyun ağrısı ekstremite ağrısından daha şiddetlidir. Ekstremite ağrısı olabilir, ancak bu durum spinal sinir kökü basısından çok somatik yansıma ağrısıdır. Ağrı, boynun aynı pozisyonda uzun sürelerle kaldığı bilgisayar kullanımı, okuma ya da otomobil kullanma gibi durumlarda şiddetlenir. Beraberinde kas spazmı ve sertliği eşlik eder. Fizik bakıda, boyun eklem hareketleri sırasında ağrı ve kısıtıııı vardır. Ancak, nörolojik bakı normaldir. MR görüntüleme yöntemi ile, ağrının hangi diskten kaynaklandığını belirleyebilmek mümkün değildir. ${ }^{[10,11]}$ 


\section{Servikal Spondilosis}

Elli yaş üzerinde boyun ağrısının en sık nedenidir. ${ }^{[1,6]}$ Spondilozis terimi, yumuşak doku, disk ve servikal vertebranın dejeneratif değişikliklerinin hepsi için kullanılmaktadır. Başlangıcı sinsidir ve servikal diskojenik ağrıla birliktedir. Tüm servikal omurgayı ilgilendirir, ancak daha çok alt servikal bölgede şiddetlidir. Intervertebral diskte su içeriğinde azalma, kemik yapıda skleroz, marjinal osteofitler ve faset eklemlerde kıkırdak yüzeyinde değişiklikler ile seyreder. Servikal bölgede dejeneratif değişiklikler, genellikle normal yaşlanma sürecinin sonucu olarak 30 yaş civarında başlar ve travmatik durumlar süreci hızlandırır. ${ }^{[12]}$ Radyografik değişiklikler ile klinik yakınmalar genellikle korele degildir. Anormal radyolojik bulgular, asemptomatik kişilerde sıklıkla görülebilmektedir. ${ }^{[1,4,13]}$

\section{Servikal Faset Sendromu}

Aksiyel boyun ağrılarının sık görülen nedenlerinden biri, faset eklemlerdeki dejeneratif değişikliklerdir. Yaşla birlikte görülme sıklığı artar. Üst servikal bölgede özellikle C4-C5 arasında daha sık görülür. ${ }^{[14]}$ Öyküde, boyunda ani fleksiyon ve ardından ekstansiyonun eşlik ettiği travmatik kamçı yaralanması ya da mesleki olarak boyunda tekrarlayıcı ekstansiyon postür zorlanmaları vardır. ${ }^{[15]}$ Ağrı genellikle boyun orta hattadır; somatik yayılma ile omuz, periskapular bölge, oksiput veya proksimal ekstremiteye yayılabilse de, aksiyel semptomlar her zaman ekstremite semptomlarından daha ön plandadır. Ağrı, genellikle boyun ekstansiyonu ile agreve olur. ${ }^{[16]}$ Faset eklem kaynaklı ağrı yayılımı genellikle aşağıdaki paterndedir:

\section{C1-2, C2-3: Yukarı oksiput \\ C3-4, C4-5: Boyun arkası \\ C5-6: Skapula supraspinatus fossa \\ C6-7: Skapula üzeri \\ C1-2, C2-3, C3-4: Yüze yansıyabilir}

Faset sendromunda, tanıyı kesinleştirmek üzere tanımlanmış spesifik muayene bulgusu ya da görüntüleme yöntemi yoktur. Tanısal amaçlı yapılan floroskopi rehberliğinde intraartiküler lokal anestezik madde enjeksiyonları ile hastanın yakınmalarının rahatlaması, tanıyı kesinleştiren en güvenilir yöntem olarak kabul edilir.

\section{Kamçı Yaralanması}

Servikal omurganın ani ve şiddetli travmatik fleksiyon-ekstansiyon hareketi ile meydana gelir. Yumuşak dokular, spinal sinir, intervertebral disk, posterior longitudinal bağ, interspinöz bağ, faset eklemler ve diğer osseöz dokular yaralanabilir. Boyun sırt ve oksipital bölgede şiddetli ağrı, spazm, kısıtlılık, oksipital baş ağrısı vardır. Tanısal amaçla yapılan X-ray, MR gibi görüntüleme yöntemlerinde belirgin patoloji gösterilemese de, kamçı yaralanmasına bağlı ağı kronikleşme potansiyeline sahiptir. Bir sistematik derlemede, 47 çalışmanın sonuçları incelenmiş ve bu çalışmalardaki tüm kamçı yaralanması geçiren hastaların yarısında bir yıl sonra boyun ağrısının hala devam ettiği gösterilmiştir.[17]

\section{Servikal Miyofasyal Ağrı}

Kas içi tetik nokta, gergin bantlar ve basınca karşı hassasiyetle karakterize lokalize ağrıdır. Servikal paravertebral kaslar ve trapez kasta sıklıkla görülür. Özellikle kötü postürde uzun sürelerle çalışanlarda görülmektedir. Miyofasyal ağrı, boyun ağrısına yol açan birçok durumda birlikte olabilir. Hasta, tipik olarak boyun üst trapez ve skapula çevresi ağrıdan ve tutukluktan yakınır. Ağrı, referans zonu ile kola yayılabilir, ancak nörolojik bulgu eşlik etmez.

\section{BOYUN-KOL AĞRISI VE NÖROLOJIK DEFISIT YAPAN DURUMLAR}

\section{Servikal Radiküler Ağrı}

Servikal sinir kökünün nörofizyolojik işlev kaybıyla giden süreçtir. En sık nedeni, servikal disk hernisi ya da servikal spondiloza bağı kök basısıdır; ancak, tümör, travma ve diyabete bağlı radiküler ağrı da olabilir. Kol ağrısı boyun ağrısından belirgindir. ${ }^{[4]}$ Servikal disk herniyasyonu için riskli yaşlar, 40-50 yaşlar arasıdır. Genellikle ağır kaldırarak çalışanlarda, uzun sürelerle otomobil kullananlarda ve sigara içenlerde daha sık görülür. Servikal disk herniyasyonu, \%45-60 oranında olmak üzere en sık C6-C7 arasında görülür ve bu düzeyde C7 kökü komprese olur. Daha sonra \%20-25 oranında C5-C6 düzeyinde olan herniyasyon ile C6 kök kompresyonu meydana gelir. C8-T1 \%20-25 oranında herniye ve C8 kökü komprese olur. Servikal disk herniyasyonlarının en az görüldügü yer \%10 oranında C4C5 arasındadır. ${ }^{[18]}$ Hastanın genellikle ağrısı boyundan kola yansır ve eşlik eden duyusal ya da motor semptomlar mevcuttur. Servikal radiküler ağrı ile servikal strain, spondiloz ve kamçı yaralanması olan hastaların klinik özellikleri ve bulguları arasındaki farklılıklar Tablo 1'de özetlenmiştir.

\section{Servikal Spondilotik Miyelopati}

Servikal spondilotik miyelopati, servikal spinal kanaldaki dejeneratif değişikliklerin spinal kanalı daraltarak servikal spinal kordda yaralanma ya da disfonksiyona yol açmasıdır. Genelde 50 yaş üzeri erkeklerde görülür. Hastada çok çeşitli nörolojik etkilenme 
Tablo 1. Servikal strain, disk hernisi, servikal spondiloz ve kamçı yaralanması olan hastaların klinik özellikleri ve bulguları arasındaki farklar

\begin{tabular}{|c|c|c|c|c|c|}
\hline Mekanik & Karakteri & Yeri & Fizik Bakı & Radyoloji & Tanı \\
\hline $\begin{array}{l}\text { Strain (derin } \\
\text { somatik ağrı) } \\
\text { Hafif } \\
\text { Şiddetli }\end{array}$ & $\begin{array}{l}\text { Akut (keskin) } \\
\text { Kronik (Ag̉rı) } \\
\text { Keskin }\end{array}$ & $\begin{array}{l}\text { Boyundan } \\
\text { interskapular ve } \\
\text { omuz başına } \\
\text { yayılır }\end{array}$ & $\begin{array}{l}\text { Palpasyonda } \\
\text { hassasiyet } \\
\text { Spazm } \\
\text { EHA azalması }\end{array}$ & Normal & $\begin{array}{l}\text { Hikaye, fizik } \\
\text { bakı }\end{array}$ \\
\hline $\begin{array}{l}\text { Disk hernisi } \\
\text { (Radiküler) C3-4 } \\
\text { (C4 kökū) }\end{array}$ & $\begin{array}{l}\text { Keskin ağn, } \\
\text { uyuşma }\end{array}$ & $\begin{array}{l}\text { Boyundan levator } \\
\text { skapula ve ant. } \\
\text { göğüs }\end{array}$ & $\begin{array}{l}\text { Azalmış EHA, Palp. } \\
\text { hassasiyet, } \\
\text { Nörolojik bakı N }\end{array}$ & $\begin{array}{l}\text { C3-4 dik } \\
\text { hernisi }\end{array}$ & $\begin{array}{l}\text { Hikaye, Fizik } \\
\text { bakı, } \\
\text { Konformasyon } \\
\text { için radyoloji }\end{array}$ \\
\hline $\begin{array}{l}\text { Disk hernisi } \\
\text { (Radiküler) C4-5 } \\
\text { (C5 kökü) }\end{array}$ & $\begin{array}{l}\text { Keskin aḡn, } \\
\text { uyuşma }\end{array}$ & $\begin{array}{l}\text { Boyundan omuz } \\
\text { başı, ant. göğüs }\end{array}$ & $\begin{array}{l}\text { Azalmış EHA, Palp. } \\
\text { hassasiyet, duyu: } \\
\text { deltoid alanı, } \\
\text { motor: deltoid, } \\
\text { biseps, DTR: biseps }\end{array}$ & $\begin{array}{l}\text { C4-5 disk } \\
\text { hernisi }\end{array}$ & $\begin{array}{l}\text { Hikaye, Fizik } \\
\text { bakı, } \\
\text { Konformasyon } \\
\text { için radyoloji }\end{array}$ \\
\hline $\begin{array}{l}\text { Disk hernisi } \\
\text { (Radiküler) C5.6 } \\
\text { (C6 kökü) }\end{array}$ & $\begin{array}{l}\text { Keskin ağn, } \\
\text { uyuşma }\end{array}$ & $\begin{array}{l}\text { Boyundan omuz, } \\
\text { skapula } \\
\text { mediali, kol } \\
\text { laterali, önkol } \\
\text { dorsali }\end{array}$ & $\begin{array}{l}\text { Azalmış EHA, Palp. } \\
\text { hassasiyet, duyu: } \\
\text { 1., 2. parmak alanı, } \\
\text { motor:, biseps, DTR: } \\
\text { biseps }\end{array}$ & $\begin{array}{l}\text { C5-6 disk } \\
\text { hernisi }\end{array}$ & $\begin{array}{l}\text { Hikaye, Fizik } \\
\text { bakı, } \\
\text { Konformasyon } \\
\text { için radyoloji }\end{array}$ \\
\hline $\begin{array}{l}\text { Disk hernisi } \\
\text { (Radiküler) C6-7 } \\
\text { (C7 kökü) }\end{array}$ & $\begin{array}{l}\text { Keskin ağn, } \\
\text { uyuşma }\end{array}$ & $\begin{array}{l}\text { Boyundan omuz, } \\
\text { skapula } \\
\text { mediali, kol } \\
\text { laterali, önkol } \\
\text { dorsali }\end{array}$ & $\begin{array}{l}\text { Azalmıs EHA, } \\
\text { Palp. hassasiyet, } \\
\text { duyu: 3., 4. parmak } \\
\text { alani, motor:, } \\
\text { triseps, DTR: triseps }\end{array}$ & $\begin{array}{l}\text { C6-7 disk } \\
\text { hernisi }\end{array}$ & $\begin{array}{l}\text { Hikaye, Fizik } \\
\text { bakı, } \\
\text { Konformasyon } \\
\text { için radyoloji }\end{array}$ \\
\hline $\begin{array}{l}\text { Disk hernisi } \\
\text { (Radiküler) C7- } \\
\text { T1 (C8 kökü) }\end{array}$ & $\begin{array}{l}\text { Keskin ağn, } \\
\text { uyuşma }\end{array}$ & $\begin{array}{l}\text { Boyundan omuz } \\
\text { Lateral önkol }\end{array}$ & $\begin{array}{l}\text { Azalmış EHA, Palp. } \\
\text { hassasiyet, duyu:, } \\
\text { 4.5. parmak alani, } \\
\text { motor:, el kaslan }\end{array}$ & $\begin{array}{l}\text { C7-T1 disk } \\
\text { hernisi }\end{array}$ & $\begin{array}{l}\text { Hikaye, Fizik } \\
\text { bakı, } \\
\text { Konformasyon } \\
\text { için radyoloji }\end{array}$ \\
\hline $\begin{array}{l}\text { Servikal } \\
\text { spondiloz } \\
\text { (Derin somatik) }\end{array}$ & Aḡrı & Boyun & Azalmıs EHA & $\begin{array}{l}\text { Disk ve faset } \\
\text { eklem aralığı } \\
\text { azalması }\end{array}$ & $\begin{array}{l}\text { Hikaye, Fizik } \\
\text { bakı, radyoloji }\end{array}$ \\
\hline $\begin{array}{l}\text { Kamçı } \\
\text { yaralanması } \\
\text { (derin somatik) }\end{array}$ & Ağrı & $\begin{array}{l}\text { Boyundan } \\
\text { interskapular ve } \\
\text { omuza }\end{array}$ & $\begin{array}{l}\text { Kas spazmı, } \\
\text { Azalmıs EHA }\end{array}$ & & $\begin{array}{l}\text { Hikaye, fizik } \\
\text { bakı }\end{array}$ \\
\hline
\end{tabular}

bulguları olabilir. Ekstremite distallerinde uyuşukluk, parestezi, alt ekstremite kaslarında güçsüzlük, koordinasyon problemleri, yürüme güçlügüü, mesane-barsak ve seksüel disfonksiyonlar görülür. Ayırıcı tanıda siringomiyeli, multipl skleroz, amiyotrofik lateral skleroz, epidural abse ve tümörler akla gelmelidir. Hastalığın doğal seyri çok iyi bilinmemektedir. ${ }^{[4]}$ Uzun süre sessiz kalabilir. Erken dönemde, bacaklarda henüz hafif güçsüzlük ve minimal yürüme bozukluğu varken, ayrıntılı fizik bakıda saptanan hiperrefleksi ve Babinski bulgusu servikal miyelopatinin saptanmasına yardımcı bulgulardır. Bacaklardaki rahatsızlık hissi ve yanıcı paresteziler, siyatalji ile karıştırılabilir; ya da ellerdeki hafif beceriksizlik ve paresteziler servikal miyelopatinin erken dönem bulguları olabilir ve median sinir nöropatisi ile karıştırılabilir. Lhermitte bulgusu bazı hastalarda pozitif saptanabilir, tanıya yardımcıdır. ${ }^{[4,6]}$

\section{SONUÇ}

Boyun ağrısı pek çok faktöre bağlı gelişen bir klinik durumdur. Ayrıntılı öykü ve fizik bakı, tanı ve ayırıcı tanı süreçleri açısından çok önemlidir. Öncelikle, altta yatan ciddi patolojik durumların dışlanması gereklidir. Daha sonra da mekanik ağrının radiküler ya da miyelopatiden ayırt edilmesi gerekir. 


\section{KAYNAKLAR}

1. Guzman J, Haldeman S, Carroll LJ, Carragee EJ, Hurwitz EL, Peloso P, Nordin M, Cassidy JD, Holm LW, Côté P, van der Velde G, Hogg-Johnson S; Bone and Joint Decade 20002010 Task Force on Neck Pain and Its Associated Disorders. Clinical Practice implications of the Bone and Joint Decade 2000-2010 Task Force on Neck Pain and Its Associated Disorders; from concepts and findings to recommendations. Spine; 2008;33(4 Suppl):S199-213. Crossref

2. Honet JC, Ellenberg MR. What you always wanted to know about the history and physical examination of neck pain but were afraid to ask. Phys Med Rehabil Clin N Am 2003;14(3):473-91.

3. Rubinstein SM, van Tulder M. A best-evidence review of diagnostic procedures for neck and low-back pain. Best Pract Res Clin Rheumatol 2008;22(3):471-82. Crossref

4. Alexander EP. History, physical examination, and differential diagnosis of neck pain. Phys Med Rehabil Clin N Am 2011;22(3):383-93. Crossref

5. Borenstein DG. Neck Pain, Appendix B. In: Borenstein DG, editor. Low Back and Neck Pain, 4th ed. Philadelphia: WB Saunders Comp; 2004.

6. Evans G. Identifying and treating the causes of neck pain. Med Clin N Am 2014;98(3):645-61. Crossref

7. Okada E. Matsumoto M, Ichihara D, Chiba K, Toyama Y, Fujiwara H, Momoshima S, NishiwakiY, Hashimoto T, Ogawa J, Watanabe M, Takahata T.Aging of the cervical spine in healthy volunteers: a 10-year longitudinal magnetic resonance imaging study. Spine (Phila Pa 1976) 2009;34(7):706-12.

8. Grubb SA, Kelly CK. Cervical discography: clinical implications from 12 years of experience. Spine (Phila Pa 1976) 2000;25(11):1382-9.

9. Slipman CW, Plastaras C, Patel R, Isaac Z, Chow D, Garvan C, Pauza K, Furman M. Provocative cervical discography symptom mapping. Spine J 2005;5(4):381-8.
10. Boden SD, McCowin PR, Davis DO, Dina TS, Mark AS, Wiesel $\mathrm{S}$. Abnormal magnetic-resonance scans of cervical spine in asymptomatic subjects. A prospective investigation. J Bone Joint Surg Am 1990;72(8):1178-84.

11. Schelihas KP, Smith MD, Gundry CR, Pollei SR. Cervical discogenic pain. Prospective correlation of magnetic resonance imaging and discography in asympthomatic subjects and pain sufferers. Spine (Phila Pa 1976) 1996;21(3):300-11.

12. Cailliet $R$, Ananthalkrishnan D, Burns $S$. Neck pain: anatomy pathophysiology, and diagnosis. In: O'Young BJ, Young MA, Stiens SA, editors. Physical Medicine and Rehabilitation Secrets, 3rd ed. Elsevier Health Sciences; 2008. p.319-22.

13. Teresi LM, Lufkin RB, Reicher MA, Moffit BJ, Vinuela FV, Wilson GM, Bentson JR, Hanafee WN. Asymptomatic degenerative disc disease and spondylosis of the cervical spine: MR imaging. Radiology 1987;164(1):83-8.

14. Lee MJ, Riew KD. The prevalence cervical facet arthrosis: an osseous study in a cadaveric population. Spine J 2009;9(9):711-4. Crossref

15. Lord S, Barnsley L, Wallis BJ, McDonald GJ, Bogduk N. Percutaneous radio-frequency neurotomy for chronic cervical zygapophyseal-joint pain. N EnglJ Med 1996;335(23):1721-6.

16. Ivancic PC, Pearson AM, Pajabi MM, Ito S. Injury of the anterior longitudinal ligament during whiplash simulation. Eur Spine J 2004;13(1):61-8.

17. Carroll LJ, Holm LW, Hogg-Johnson S, Côté P, Cassidy JD, Haldeman S, Nordin M, Hurwitz EL, Carragee EJ, van derVelde G, Peloso PM, Guzman J; Bone and Joint Decade 2000-2010 Task Force on Neck Pain and Its Associated Disorders. Course and prognostic factors for neck pain in whiplash-associated disorders (WAD): results of Bone and Joint Decade 20002010 Task Force on Neck Pain and Its Associated Disorders. Spine (Phila Pa 1976) 2008;33(4 Suppl):S83-92. Crossref

18. Levin KH, Covington EC, Devereaux MW, et al. Neck and Low Back Pain, Vol 7. New York: Continuum; 2001. p.1-205. 